\title{
Dioclein - a new drug from an old plant
}

\author{
Lefter from Brazil
}

\author{
John Dunn
}

Preservation of the world's rainforests and other natural habitats can be argued for from several points of view. Maintaining biodiversity and preventing the 'greenhouse effect' are two commonly stated objectives. A less altruistic reason is that many of the floral species in such habitats remain unstudied and could yield new and important drugs to treat human diseases. Many of the drugs we use today are derived from plants or are their synthetic derivatives.

While some plants are chosen at random for laboratory testing, others are selected because they are already being used in folk medicines. Most street markets in Brazil have stalls where it is possible to buy a wide variety of dried roots, leaves and other plant parts, each indicated for a specific ailment. Furthermore, herbal chemists selling 'natural' preparations, can be found on almost every high street. The plant Dioclea grandiflora, or macunã as it is popularly called, is a type of vine belonging to the Leguminosae family and is well known in Brazil for its medicinal properties. The plant does not actually grow in the rainforest but in the semi-arid regions in the northeast of Brazil. An infusion made from its roots is used as a herbal remedy for kidney stones and prostate gland disorders (Batista, 1993).

In Brazil there are many herbal preparations that are alleged to have analgesic effects, several of which have been subject to laboratory investigation. Di Stasi et al (1988) studied a crude extract from the plant Serjania ammunis and confirmed that it possessed analgesic properties. Following on from this line of research, investigators at the Federal University of Paraiba in Northeast Brazil set out to study whether constituents of the plant $D$. grandiflora would show analgesic effects in rodents (Batista et al, 1995; Bhattacharyya et al, 1995).

The process of extraction involves the dried and ground root-bark being dissolved in $90 \%$ ethanol and percolated at room temperature. The residue is then divided in two and dissolved in either water or chloroform to extract the water and fat-soluble components. These underwent further processes of purification before being tested in rats.

Two animal models are commonly used both to induce pain and measure analgesic effect: the acetic acid-induced writhing test and the tailflick test (Koster et al, 1959). In the former test, acetic acid is injected intraperitoneally where it induces repeated characteristic stretching movements that can be inhibited by the prior administration of analgesics. In the latter test, a thermal stimulus is aimed at the rodent's tall and the latency period for the animal to flick its tail out of the beam is measured. Administration of the purified extracts from the plant $D$. grandiflora caused a significant reduction in acetic acid-induced writhing. suggesting that the substance has an analgesic effect. In the tailflick test, the substance significantly increased reaction time and when compared to morphine appeared to have a longer duration of action. Pretreatment of the rodents with the opiate antagonist naloxone attenuated the analgesic action of the drug, suggesting that it possesses a central opiate-like action.

Chemical analysis of the plant extract, involving column chromatography, crystallisation and mass spectrometry, revealed a substance with the chemical formula $\mathrm{C}_{17} \mathrm{H}_{16} \mathrm{O}_{7}$ or $5,2^{\prime}, 5^{\prime}$ trihydroxy-6,7-dimethoxyflavanone, which the researchers named dioclein.

The popular press was quick to pick up on this work, announcing that a Brazilian plant had been found with properties similar to morphine. The researchers were interviewed and quoted as reporting that further tests had suggested dioclein did not cause tolerance. This was misinterpreted by the reporters as evidence that taking the substance would not lead to dependency, a finding heralded as a tremendous breakthrough and a great advantage over morphine.

Such new discoveries need to be received with a cautious welcome, in particular it is too early to settle the question of whether dioclein will cause 
tolerance or dependency in man. As a cautionary tale it should be remembered that in 1874 a new opiate was manufactured in St Mary's Hospital, London. It was named diacetylmorphine - later to become known as diamorphine or heroin. By 1898 the Bayer Pharmaceutical Company had begun commercial production of the drug, which in its early years was used as a 'cure' for morphine dependence. Only later was it discovered that its dependency potential surpassed that of morphine, as the large number of heroin addicts in many Western and Eastern countries testifies.

\section{References}

BAtistA. J. S. (1993) Estudo químico e farmacológico de cascas das raizes da Dioclea grandiflora Mart. ex Benth. IA chemical and pharmacological study of the root-bark of Dloclea grandiflora Mart. ex Benth.]. Masters Thesis, Faculty of Pharmacy. Federal Untversity of Paraiba, Brazdl.

- , Almeida, R. N. \& Bhattacharyya, J. (1995) Analgesic effect of Dioclea grandiflora constltuents in rodents. Journal of Ethnopharmacology, 46, 207-210.

BHATTACHARYYA, J., BATISTA, J. S. \& ALMEIDA, R. N. (1995) Dioclein, a flavanone from the roots of Dioclea grandiflora. Phytochemistry, 38, 277-278.

Di Stasi, L. C., Costa, M., MEndacolu S, L. J., et al (1988) Screening in mice of some medicinal plants used for analgesic purposes in the State of São Paulo. Joumal of Ethnopharmacology, 24, 205-211.

Koster, R. ANDERson, M. \& DE BEER, E. J. (1959) Acetic acid for analgesic screening. Federation Proceedings, 18, 412.

John Dunn, visiting researcher and postgraduate student, Departamento de Psiquiatria, Escola Paulista de Medicina, Rua Botucatu, 740, São Paulo - SP, Brazil 04023-900

\section{Books from Gaskell

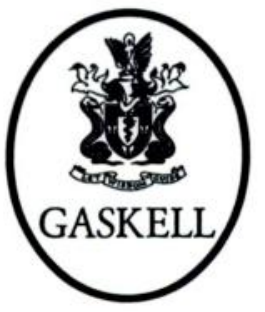 \\ Psychiatry for the Developing World \\ Edited by Digby Tantam, Louis Appleby \& Alice Duncan \\ Written by psychiatrists from the developing world, this is an up-to-date and comprehensive multi-author volume on psychiatry as it can be practiced in developing countries today. All aspects of psychiatry are covered, including administrative, practical, and planning advice, training and conducting research. Recommendations on treatment of common psychiatric disorders are also provided, following ICD-10 classification standards. Price $£ 25.00,376$ pp., 1996, ISBN 0902241869}

Available from good bookshops and from the Publications Department, Royal College of Psychiatrists, I 7 Belgrave Square, London SWIX 8PG (Tel. 017 I-235 235I, extension I46) 